\title{
Ecology and reproductive biology of the hydrothermal vent polychaete Amphisamytha galapagensis (Ampharetidae)
}

\author{
Damhnait McHugh ${ }^{1, *}$, Verena Tunnicliffe $\mathrm{e}^{1,2}$ \\ ${ }^{1}$ Department of Biology and ${ }^{2}$ School of Earth and Ocean Sciences, University of Victoria, British Columbia, Canada V8W 2 Y2
}

\begin{abstract}
The ampharetid polychaete Amphisamytha galapagensis Zottoli, 1983 is known from hydrothermal vent sites in the eastern and western Pacific, and has been reported from the Atlantic. Pacific specimens are apparently conspecific, but closer examination of the global species is necessary. We examined ecological and reproductive features for an explanation of the wide distribution of this species, which is unusual among vent animals (unique, if truly global in distribution). The worm, present in $95 \%$ of the collections from the Juan de Fuca and Explorer Ridges in the northeast Pacific, occurs in a wide variety of vent habitats. It appears to take advantage of vestimentiferan tubes to increase substratum area but also colonizes active smokers, sediments and other animals. A. galapagensis is gonochoric, and all stages of egg and sperm development were present in populations sampled at different times of the year. Eggs reach $240 \mu \mathrm{m}$ in diameter and fecundity is relatively high; no modifications in sperm ultrastructure were seen. From comparison with other polychaetes, we propose that $A$. galapagensis undergoes continuous reproduction with external fertilization resulting in demersal, lecithotrophic larvae. The proposed reproductive mode of $A$. galapagensis is not unique among vent animals, and shows no unusual adaptation for long range dispersal even though the adult distribution is wide. We propose that broad ecological tolerances, habitat flexibility and reduced dispersal may be more important in allowing establishment of $A$. galapagensis at new sites once it arrives. Further study in population genetics, systematics and development is important in a species that could provide much insight into the evolution of ecological and life history patterns at ephemeral island habitats
\end{abstract}

KEY WORDS: Amphisamytha galapagensis $\cdot$ Polychaete $\cdot$ Hydrothermal vent $\cdot$ Reproduction

\section{INTRODUCTION}

Luxuriant biological communities at hydrothermal vents are supported by chemosynthetic primary productivity. The energy source, however, is unpredictable as it depends on sustained hydrothermal activity. Hydrothermal vents, which range in age from a few to hundreds of years (MacDonald et al. 1980, Lalou et al. 1984, Campbell et al. 1988. Stakes \& Moore 1989), have a global distribution that follows the mid-ocean spreading ridges and isolated back-arc

\footnotetext{
- Present address: Department of Biology and Institute of Marine Sciences, University of California, Santa Cruz, California 95064, USA
}

spreading centers. Discrete vent faunas are recognized in different oceanic realms corresponding to separation distance and spreading history (Tunnicliffe 1988, 1991, Van Dover 1990, D. Desbruyères pers. comm.). Vent fields on separate segments of a ridge may lie hundreds of kilometers apart. The extreme resource patchiness of vents is likely to be a major factor influencing biotic processes among the habitat's inhabitants.

Dispersal of species and maintenance of populations at these ephemeral island habitats can be interpreted from life histories of hydrothermal vent animals. Few accounts of reproduction and development of vent fauna have been published (for review see Tunnicliffe 1991), however, mainly because time- 
series samples from a vent are difficult to obtain and culture of vent species in the lab has yet to be achieved. Nonetheless, single samples of animals from different areas have yielded a great deal of information (e.g. Lutz et al. 1980, Le Pennec et al. 1984, Berg 1985, Turner et al. 1985, Van Dover et al. 1985, 1987, Berg \& Van Dover 1987, Cary et al. 1989. McHugh 1989, Gustafson et al. 1991, Gardiner et al. 1992). Many of these studies show that vent species exhibit a wide range of reproductive and developmental modes reflecting phylogeny of the species rather than the opportunistic life history strategies with larval dispersal stages initially predicted for such an ephemeral and patchy environment (Desbruyères \& Laubier 1983, Grassle 1985). More information on reproduction, development and growth rates is needed to understand the population dynamics of invertebrates that inhabit the vent environment (Tunnicliffe 1991, Kennish \& Lul'c 1992).

In this study, features of the ecology and life history of an ampharetid polychaete, Amphisamytha galapagensis Zottoli, 1983, are investigated. A. galapagensis is of particular interest because it has the widest known geographic range of all species reported from hydrothermal vents around the world. In this paper, we document the distribution, habitats and associations of this species, and examine several aspects of its reproductive and developmental biology.

\section{METHODS}

Ecology and distribution. Specimens of Amphisamytha galapagensis used in this study came from Juan de Fuca and Explorer Ridges in the northeast Pacific (Fig. 1). Most collections were 'grabs-of-opportunity', and none represent targeted collection for this species. Most often, vestimentiferan tube clumps were grabbed with a submersible claw in a haphazard fashion; chimney samples might be worm grabs or the broken tops of sulphide edifices. Different pilots and observers induce different collection biases, so samples may be poor representatives of the vent fauna. Specimens were bulk fixed in $7 \%$ formalin for later sorting and storage in $4 \%$ formalin or $70 \%$ ethanol.

To examine microdistribution patterns, a high temperature smoker on Endeavour Segment was sampled as follows: a flange, measuring $30 \times 40 \mathrm{~cm}$, was broken from the side of the smoker; on shipboard, a $2.5 \times$ $2.5 \mathrm{~cm}$ grid was overlaid and the animals within each square were preserved separately. Because of loss and displacement of some animals, results cannot be viewed as complete. Nonetheless, the relative positions of 6592 vent animals could be assigned, including 266 Amphisamytha galapagensis.

Reproductive biology. Specimens for study of reproductive biology came from 3 vent sites: Axial Seamount (August 1983), Endeavour Segment (September 1984) and South Explorer Ridge (June 1984) (Fig. 1). Oocytes and spermatogenic stages in formalin-fixed animals were examined under light microscopy. Specimens collected in July 1986 from Axial Seamount were fixed in 3\% glutaraldehyde in Millonig's phosphate buffer for sperm ultrastructure examination with transmission electron microscopy (TEM).

Gender was determined from coelomic samples of gametes. In 10 of the largest females from each sample, 80 oocytes were measured for maximum diameter at $100 \times$ magnification. The data on oocyte sizes were log transformed and analysis of variance (ANOVA) tests were used to identify significant differences among the sample means and to examine differences in means among females in each sample. To estimate fecundity, all oocytes from the 5 largest females in each sample were collected, and the total num. ber of oocytes in each worm was estimated by counts of three $2 \mathrm{ml}$ aliquots from a $250 \mathrm{ml}$ suspension of all oocytes.
Fig. 1. Ridges of the northeast Pacific where Amphisamytha galapagensis was collected for this study. Vent sites are located on each of the segments indicated and may be spread over tens of kilometers 
Maximum oocyte size was recorded from each coelomic sample.

In males, the occurrence frequencies of 3 stages of sperm development were noted: early rosettes of spermatocytes ( 4 to 16 cell stage), later rosettes of spermatocytes ( $>16$ cell stage) and clusters of spermatids with tail pieces. In coelomic samples from each of 5 males, all stages in 4 randomly assigned squares of a hemocytometer slide were recorded. The nephromixia of males were checked for the presence of free spermatozoa. For examination of sperm ultrastructure under TEM, gluteraldehyde-fixed worms were post-fixed in $1 \%$ osmium tetroxide at $4{ }^{\circ} \mathrm{C}$ for $1 \mathrm{~h}$. After dehydration in a graded series of ethanol and propylene oxide, they were embedded in EPON 812 and sectioned on a Reichert ultramicrotome using glass knives. Sections were stained in lead citrate and uranyl acetate before viewing on a Philips EM-300.

\section{RESULTS}

\section{Distribution}

Table 1 documents the sites at which Amphisamytha galapagensis has been found. The ampharetid reported from Snake Pit of Mid-Atlantic Ridge (Segonzac 1992) resembles $A$. galapagensis; however, specimens from the Florida Escarpment were apparently misidentified and do not belong to the genus Amphisamytha (D. Desbruyères pers. comm.). To date, the species is known for sure only from the Pacific. Nonetheless, comparison with the distributions of

Table 1. Reports of presence of the polychaete Amphisamytha galapagensis. Note that the Florida Escarpment is a seep, not a vent site

\begin{tabular}{|ll|}
\hline Site & Source \\
\hline Equatorial Eastern Pacific & \\
Galapagos Rift & Zottoli (1983) \\
$13^{\circ}$ N, East Pacific Rise & Desbruyères et al. (1985) \\
$21^{\circ}$ N, East Pacific Rise & Grassle (1985) \\
Guaymas Basin, EPR & Grassle (1985) \\
Northeastern Pacific & \\
Juan de Fuca and Explorer Ridges & Tunnicliffe (1991) \\
Western Pacific & \\
Marianas Back-Arc Basin & Hessler \& Lonsdale (1991) \\
Manus Back-Arc Basin & Galkin (1992) \\
Lau and Fiji Back-Arc Basins & D. Desbruyères pers. comm. \\
Atlantic & \\
Mid-Atlantic Ridge & Segonzac (1992) ${ }^{b}$ \\
Florida Escarpment & Petrecca \& Grassle (1990) ${ }^{c}$ \\
& \\
a Reported as Amphisamytha aff. galapagensis & \\
${ }^{b}$ Reported as Ampharetidae gen. sp.; see text \\
cSpecimens apparently misidentified (D. Desbruyères pers. comm.)
\end{tabular}

other vent species (Tunnicliffe 1991 and unpubl. data) shows that $A$. galapagensis is recorded at more sites than any other species.

On a provincial scale, it is equally ubiquitous. We have sorted collections from 56 vents along the Explorer and Juan de Fuca Ridges that span a distance of $550 \mathrm{~km}$, and Amphisamytha galapagensis was present at 52 vents (Table 2, Fig. 1) that range from diffuse low temperature flows on new basalt to large high temperature sulphide structures in a mature field. The 4 vents with no $A$. galapagensis specimens hold no obvious common features. Often the worm has a clumped distribution and a single grab might not contain it, therefore we may have missed sampling it. The proportion of the total fauna represented by this species (Table 2) varied from negligible to $67 \%$; in half the ennumerated samples, this species represented over $4 \%$ of the total count. The few samples in which it was found in great abundance (over $25 \%$ ) were old chimneys with diminished flow and many dead tubeworms.

Collections from Cleft Segment (Fig. 1) spanned many vent types, and they were analyzed together as collection methods tended to be uniform. Ridgeia piscesae, Paralvinella sulfincola and Amphisamytha galapagensis are 3 of the most abundant species at Cleft Segment (6) species comprise over $90 \%$ of all collections: B. Milligan pers. comm.). The abundances of A. galapagensis are significantly correlated with those of $R$. piscesae, the vestimentiferan (Spearman correlation coefficient $=0.488, \mathrm{n}=28, \mathrm{p}<0.01$ ). No significant relationship was found with abundances of the polychaete $P$. sulfincola, however.

Fine-scale distribution of Amphisamytha galapagensis was examined on the sulphide flange collected from Endeavour Segment. Hot water pooling under the flange measured a maximum of $260^{\circ} \mathrm{C}$ from where it trickled upward over the nose of the flange and bathed a dense mat of animals on the upper side (J. Holden pers. comm.). The occurrence of species across the flange corresponded to water flow: where hot water emerged around one side, the polychaete Paralvinella sulfincola predominated; on the cooler side, Ridgeia piscesae tubes were abundant. A. galapagensis occurred on both sides. Within the sample, A. galapagensis abundances are correlated to those of the vestimentiferan (Spearman correlation coefficient $=0.400, \mathrm{n}=108, \mathrm{p}<0.001$ ) and again showed no significant relationship with $P$. sulfincola. The ratio of adult $A$. galapagensis to 'juveniles' $(<5 \mathrm{~mm}$ length, but see 'Reproductive biology' section below) in 


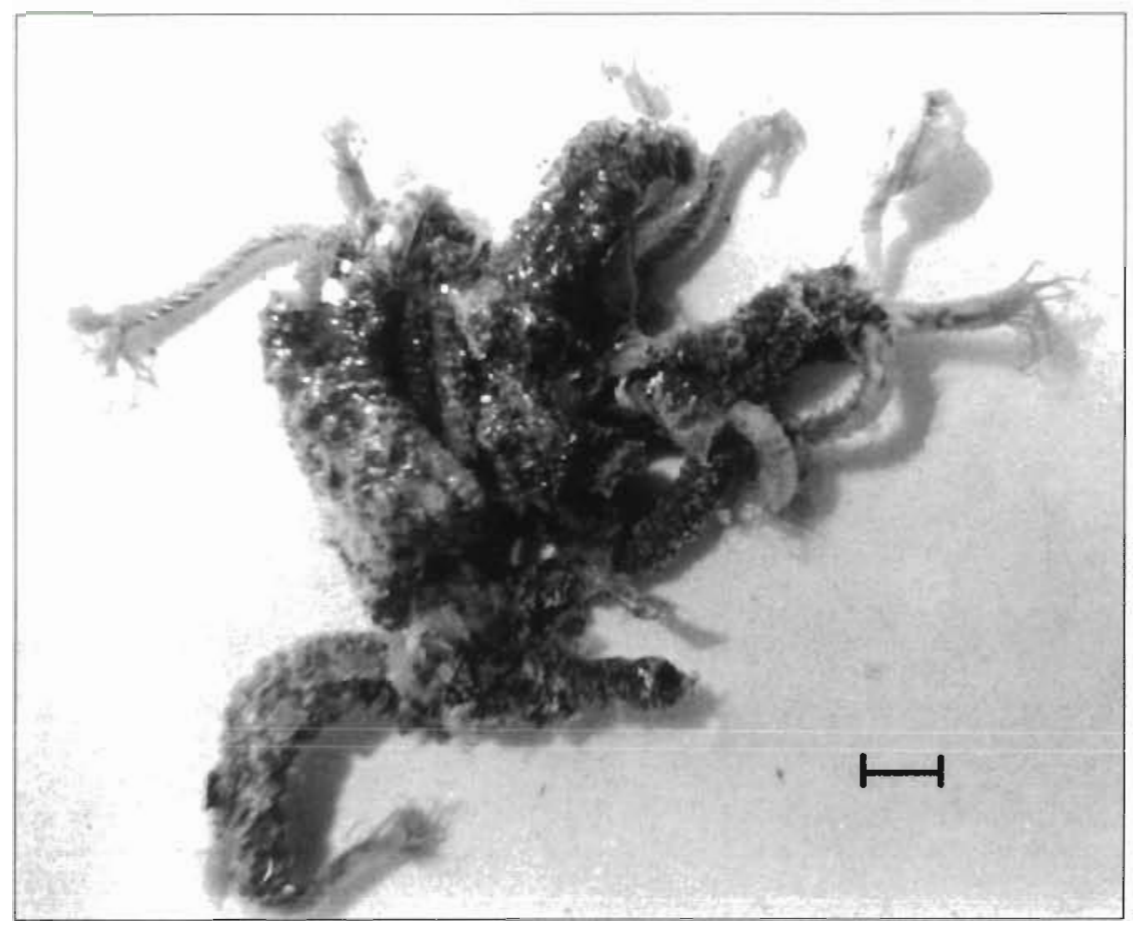

Fig. 2. Amphisamytha galapagensis. Live worms on shipboard. Anterior filaments are branchiae. Black mass is coalesced tubes made of sulphide particulates and mucus. Scale bar $=1 \mathrm{~cm}$ crawl actively. At $13^{\circ} \mathrm{N}$ on East Pacific Rise, we found this species free-living around the mouthparts of the vent crab Cyanograea praedator; it has also been noted on the crab Bythograea thermydron (Desbruyères \& Laubier 1983). Like other ampharetids, $A$. galapagensis apparently uses its buccal tentacles for deposit feeding; several specimens had sulphide particles and bacterial filaments in the gut.

\section{Reproductive biology}

Amphisamytha galapagensis is gonochoric and chi-square tests of the 3 samples showed no significant difference from a $1: 1$ male: female sex ratio $(p<0.001)$. Gametes are released at an early stage into the coelom, where development proceeds. Coelomic gametes are found in worms as small as $3.5 \mathrm{~mm}$ in length, which is approximately $20 \%$ of the max-

this sample is 1.2:1.0. Abundances of the 2 size classes examined over the gridded flange are correlated (Spearman correlation coefficient $=0.530, \mathrm{n}=108$, $\mathrm{p}<0.001$ )

Amphisamytha galapagensis occurs in a wide variety of vent habitats. We found it most commonly attached to vestimentiferan worms in a flexible particulate tube bound by mucus, and usually free at the upper end (Fig. 2). The worm may also construct recumbent tubes on rock surfaces, and was seen on active sulphide chimneys near the venting spout. Tubes were also found projecting from sediments at the base of smoker chimneys. However, A. galapagensis is frequently without a tube and specimens can imum length. Fig. 3 shows size frequencies of coelomic gametes in females from the 3 sites. A similar wide range of oocyte sizes is recorded from each site and this size range is repeated in each female in the 3 samples. The ANOVA test reveals significant differences between sample means and the overall mean $(F=$ $63.43, \mathrm{df}=2, \mathrm{p}<0.0001$ ). This difference indicates variability in the reproductive cycle among the 3 populations; both the Axial Seamount and the Explorer Ridge populations have higher proportions of larger oocytes than the Endeavour Segment population (Fig. 3).

Significant differences exist between individual means of oocyte size and sample means (Axial Seamount: $F=2.39$, df $=9, p<0.0113$; Explorer Ridge:

Table 2. Occurrence of the ampharetid polychaete Amphisamytha galapagensis at vents on the spreading ridges in the northeast Pacific. Listing indicates the numbers of vents at which the worm was found and, for enumerated samples, the proportion of the fauna ( $>5 \mathrm{~mm}$ size) represented by $A$. galapagensıs. n: sample size; na: not available

\begin{tabular}{|c|c|c|c|c|c|}
\hline \multirow{2}{*}{$\begin{array}{r}\text { Ridge: } \\
\text { Site: }\end{array}$} & \multicolumn{2}{|c|}{ Explorer } & \multicolumn{3}{|c|}{ Juan de Fuca } \\
\hline & South Segment & Middle Valley & Endeavour Segment & Axial Seamount & Cleft Segment \\
\hline No. of vents sampled & 6 & 3 & 12 & 17 & 18 \\
\hline No. of vents with $A$ galapagensi & sis & 3 & 12 & 16 & 15 \\
\hline $\begin{array}{l}\text { Proportion of } A . \text { galapagensis } \\
(\mathrm{n}, \mathrm{SD})\end{array}$ & na & $\frac{\text { na }}{(8,24.2)}$ & $\begin{array}{c}18.8 \% \\
(1,-)\end{array}$ & $\begin{array}{c}6.6 \% \\
(28,8.7)\end{array}$ & $4.3 \%$ \\
\hline
\end{tabular}



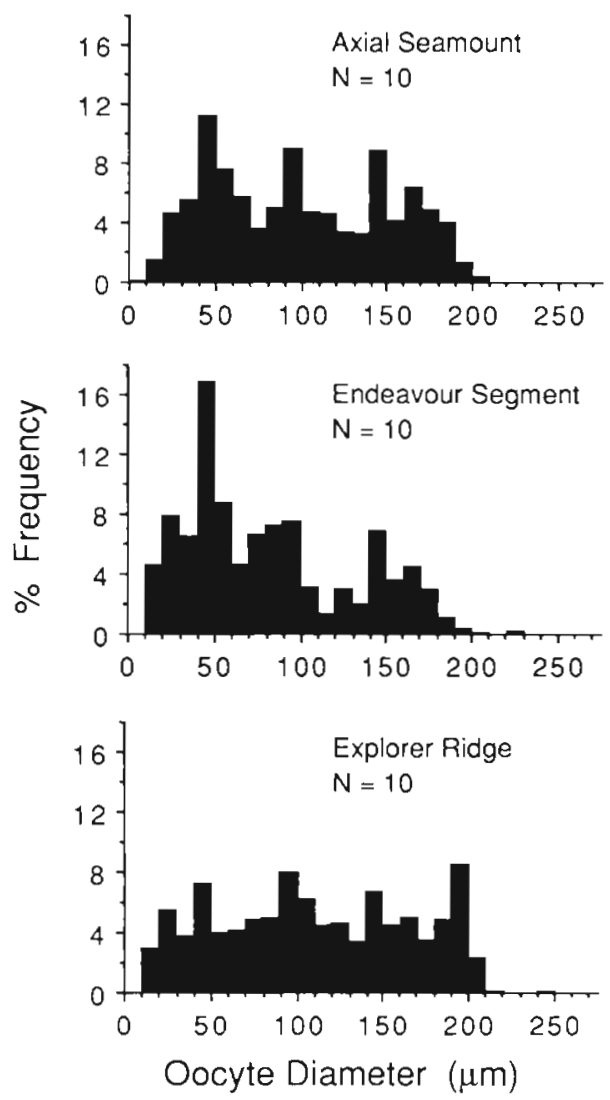

Fig. 3. Amphisamytha galapagensis. Size-frequency histograms of maximum oocyte diameter for the 3 samples of worms. N: number of females in each sample

$F=6.031, \mathrm{df}=9, \mathrm{p}<0.0001$; Endeavour Ridge: $F=4.92$, $\mathrm{df}=9, \mathrm{p}<0.0001$ ), which indicate a lack of synchronization of oocyte development among individuals in each population. In the Axial Seamount and Endeavour Segment populations, however, 1 and 2 females account for the significant differences among individuals in each sample, respectively $(p<0.05)$. Three dis-

Table 3. Amphisamytha galapagensis. Maximum oocyte diameter and maximum fecundity (no. of oocytes in an individual) recorded for worms from the 3 sites. n: sample size

\begin{tabular}{|lcc|}
\hline Site & $\begin{array}{c}\text { Maximum } \\
\text { oocyte diameter } \\
(\mu \mathrm{m})\end{array}$ & $\begin{array}{c}\text { Maximum } \\
\text { fecundity } \\
(\mathrm{n}, \overline{\mathrm{x}}, \mathrm{SD})\end{array}$ \\
\hline Axial Seamount & 215 & $\begin{array}{c}11412 \\
(5,5956,3624)\end{array}$ \\
Endeavour Segment & 225 & 9625 \\
Explorer Ridge & 240 & $(5,7768,2242)$ \\
& & 12500 \\
& & \\
\hline
\end{tabular}

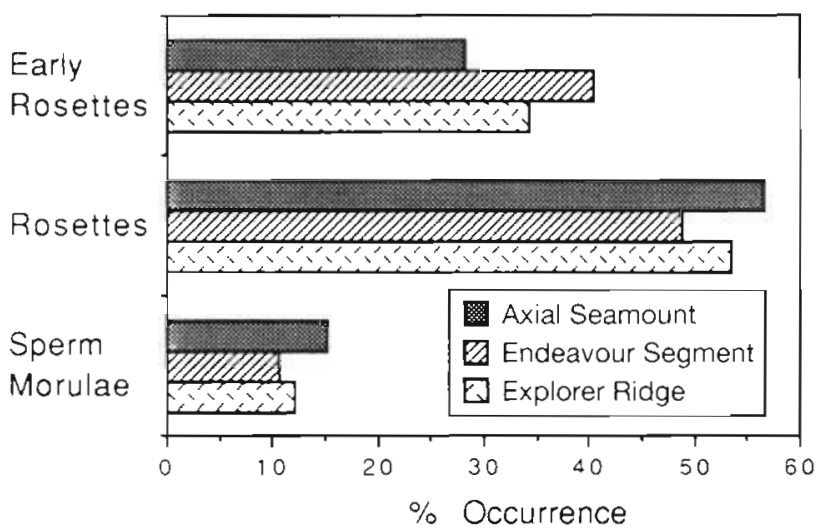

Fig. 4. Amphisamytha galapagensis. Percent occurrence of spermatogenic stages in 5 males from each of the 3 samples of worms

tinct peaks in oocyte sizes are evident in the Axial Seamount sample and, to a lesser extent, in the other 2 samples (Fig. 3). The maximum fecundity of Amphisamytha galapagensis is 12500 oocytes in a worm of $18 \mathrm{~mm}$ length $(0.0684 \mathrm{~g})$ and mean fecundity ranges from 5600 to 9600 oocytes per worm among the 3 populations (Table 3 ). Maximum oocyte size of A. galapagensis from the 3 samples ranges from 215 to $240 \mu$ m diameter (Table 3 ).

While free spermatozoa were not found in the nephromixia, the 3 spermatogenic stages were well represented in the coeloms of males from the 3 sites (Fig. 4), and mature sperm were found in males fixed for TEM. In mature sperm from the coelom, the nuclear material is condensed to a bullet-shaped nucleus and the acrosomal vesicle is thimble-shaped with a thin opaque cap (Fig. 5A). Longitudinal and cross-sectional views of the vesicle reveal regional differences in electron opacity: an electron-translucent inner border lines the main portion of the vesicle, within which a regular granular substructure is apparent in some sections; a thin layer of electron-opaque material, perhaps subacrosomal in origin, apposes the inner proximal end of the acrosomal vesicle. A prominent gap of ca $0.1 \mu \mathrm{m}$ separates the base of the acrosome and the anterior tip of the nucleus, and the fully condensed nucleus measures ca $2.7 \mu \mathrm{m}$ by ca $1.6 \mu \mathrm{m}$ (Fig. 5A). The middle piece contains 5 mitochondria surrounding the proximal and distal centrioles, and the flagellum has a $9+2$ microtubular arrangement (Fig. 5B).

\section{DISCUSSION}

The wide distribution of Amphisamytha galapagensis is unique among vent species, apparently ranging across the Pacific and possibly the Atlantic. A re- 

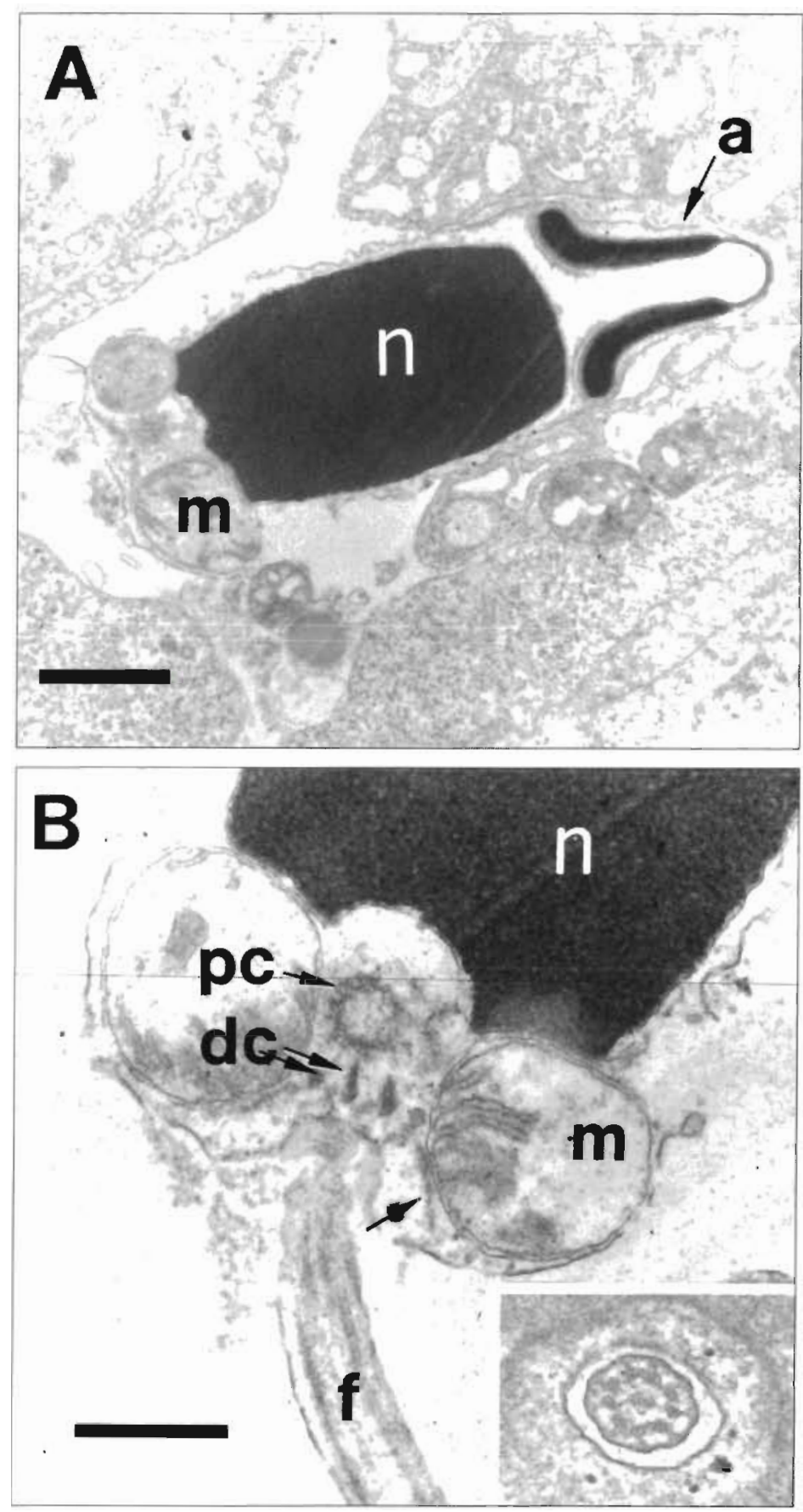

Fig. 5. Amphisamytha galapagensis. Transmission electron micrographs of sperm ultrastructure. (A) Median longitudinal section through a sperm cell. $\mathrm{a}=$ acrosome; $\mathrm{m}=$ mitochondria; $\mathrm{n}=$ nucleus. Scale bar $\approx 1.0 \mu \mathrm{m}$. (B) Longitudinal section through the flagellar apparatus showing the proximal (pc) and distal (dc) centrioles. The unlabeled arrow points to a lateral satellite. Inset shows a cross section through a flagellum (f). $\mathrm{m}=$ mitochondria; $\mathrm{n}=$ nucleus. Scale bar $\approx 0.5 \mu \mathrm{m}$

examination of the species characters is advisable, however, as D. Desbruyères (pers. comm.) expresses some concern over the variability of characters from east to west Pacific, and is doubtful about the exact affinities of the Atlantic specimens. While even sub-species or sister-species relationships have biogeographic interest, further speculation on a global perspective is premature. Even with the most conservative approach, however, the wide eastern Pacific distribution remains intriguing.

The highly adaptable nature of the worm may partly explain its wide distribution. It appears to have few requirements other than proximity to a chemosynthetic source, and the extremes of habitats it occupies are impressive. We have found this animal under a $10 \mathrm{~cm}$ thick cracked basalt crust some $50 \mathrm{~m}$ distant from a vent; no other organisms were found there. It was also collected from atop a black smoker in a zone just below Paralvinella sulfincola, the northeast Pacific species that occupies the hottest zone (Tunnicliffe et al. 1993). Amphisamytha galapagensis is reported in seeping Guaymas sediments with several other polychaetes, and as the only animal in sediments at the foot of a smoker (Grassle et al. 1985). The wide range of habitats reported here and by Desbruyères et al. (1985) is seen in no other vent species to our knowledge.

Unlike other vent species with wide distributions, Amphisamytha galapagensis is not a rare or minor species. At over $5 \%$ mean abundance in collections, it ranks as a dominant species on Juan de Fuca Ridge. Petrecca \& Grassle (1990) record densities of $2267 \mathrm{~m}^{-2}$ in Guaymas sediments, and we estimate a minimum density of $2995 \mathrm{~m}^{-2}$ on the smoker flange collected from Endeavour Segment. At such high abundances, some interactions with other species can be expected. The significant positive correlation with vestimentiferan abundances is most likely due to the increased substratum area provided by the vestimentiferan tubes. The same correlation existed whether or not the vestimentiferan tubes were occupied (tested using the flange samples). On bare chimney surfaces additional substrate is also available to this ampharetid. In neither the between-vent analysis (Cleft Segment collections) nor the within-vent analysis (Endeavour flange) did we identify a negative correlation with the alvinellid Paralvinella sulfincola. Nonetheless, substratum competition may occur, even though the alvinellid tends to locate within centimeters of the hottest flow (Tunnicliffe et al. 1993) while the ampharetid stays more distal. 
Amphisamytha galapagensis is a deposit-feeder that appears to prefer a tubicolous habit but frequently vacates its tubes; it may be free-living when tube material is scarce. It seems to have little problem colonizing vents and maintaining populations. One Cleft Segment field is known to be young - about 10 yr at collection time (Chadwick et al. 1991, Milligan \& Tunnicliffe in press) - and several Endeavour chimneys in an old field are almost extinct; $A$. galapagensis was abundant at the first and predominated at the second.

Like almost all other ampharetid polychaetes that have been studied, Amphisamytha galapagensis is gonochoric and its gametes develop freely in the coelom from an early stage. The presence of gametes in small worms indicates that maturity is reached at a relatively early stage in the life cycle. Mature specimens were recovered from panels deployed on the East Pacific Rise and Galapagos spreading center for $1216 \mathrm{~d}$ (Van Dover et al. 1988), implying that growth to maturity takes at the most $3.3 \mathrm{yr}$ in this species. The presence of a full range of oocyte sizes and all spermatogenic stages in worms from 3 vents sampled in different months of different years suggests that A. galapagensis produces gametes continuously or semi-continuously. ANOVA results imply a lack of synchrony of oogenesis among females in the 3 populations, although multiple comparison tests indicate that this result can be accounted for by a small proportion of the individuals in 2 cases. Peaks in the oocyte size-frequency histograms may represent intermittent release of oocytes into the coelom, which may cause peaks in reproductive activity when eggs mature. In the shallow water ampharetid Ampharete acutifrons, 2 spawning peaks in the females are separated by 2 mo (Clavier 1984), and peaks are also known in the continuous reproduction of the brackish water ampharetid Hypaniola kowalewskii (Marinescu 1964). The alvinellid polychaete Paralvinella pandorae, found at northeastern Pacific vents, is thought to reproduce continuously (McHugh 1989). Reproductive potential in the vent bivalve Calyptogena magnifica may be high because it becomes reproductively active at a small size and apparently reproduces continuously over a long time (Berg 1985). Also, gametogenesis occurs continuously in the vestimentiferan Riftia pachyptila (Gardiner et al. 1992).

The Polychaeta exhibit a variety of sperm morphologies, which generally correspond to fertilization modes. In species with ect-aquasperm (sensu Rouse \& Jamieson 1987), the spermatozoon generally has a short, rounded or conical head, a middle piece containing 4 to 6 mitochondria and a long flagellum with a $9+2$ microtubular arrangement. Broadcast spawning polychaetes from many families have such characteristics (for reviews see Sawada 1984, Jamieson \& Rouse
1989, Rice 1992). Specializations for the mode of fertilization (e.g. within the tube, spermatophore transfer, pseudocopulation, copulation) are usually associated with spermatozoan modifications such as an elongated nucleus, a complex acrosome or fused mitochondria. Sperm ultrastructure is known in few polychaetes of the Order Terebellomorpha and we report the first observations for an ampharetid. The invaginated conical acrosomal vesicle of Amphisamytha galapagensis is reported in other polychaete families, including the terebellid Streblosoma acymatum (Jamieson \& Rouse 1989). The variation in acrosomal electron opacity seen in A. galapagensis is common in polychaetes and may reflect compositional differences of acrosome components (Eckelbarger \& Grassle 1987). The nucleus, middle piece and tail of $A$. galapagensis sperm show no unusual characteristics. The condensed nucleus length to width ratio of 1.8 lies within the range observed among polychaetes with external fertilization (Sawada 1984). Only the acrosome of A. galapagensis sperm shows any complexity which may be related to egg envelope specializations rather than the fertilization mode. Based on these results, it is proposed that $A$. galapagensis has neither internal fertilization nor spermatophore formation. We can only speculate whether fertilization occurs in the water or in the tube. In the terebellids Ramex californiensis and Nicolea zostericola eggs are fertilized in the tube and in a mucus mass at the tube opening, respectively (Eckelbarger 1974, McHugh 1993), and both species have elongated sperm nuclei (ca $10 \mu \mathrm{m}$; pers. obs.); the terebellid Streblosoma acymatum fertilizes in the water column and has a sperm head of ca $2 \mu \mathrm{m}$ (Jamieson \& Rouse 1989). If such characteristics can be generalized, then broadcast spawning seems likely for $A$. galapagensis.

While polychaete larvae have been sampled in the plankton at and near vents on the East Pacific Rise and in the Guaymas Basin, their identification has not been possible because of their early stages of development and damaged condition (Berg \& Van Dover 1987). Therefore, we base our predictions of the development mode of Amphisamytha galapagensis on indirect evidence. In marine invertebrates, maximum oocyte size correlates well with type of larval development (Thorson 1950, Strathmann \& Vedder 1977). In polychaetes, small eggs $(<150 \mu \mathrm{m})$ are usually associated with planktotrophy while larger eggs (>150 $\mu \mathrm{m})$ give rise to lecithotrophic larvae or brooded embryos (Hermans 1979). Among ampharetids, oocytes greater than $150 \mu \mathrm{m}$ in diameter give rise to lecithotrophic, demersal larvae (Okuda 1947, Nyholm 1951, Hutchings 1973, Guillou \& Hily 1983) or to direct developing larvae (Wesenberg-Lund 1934, Marinescu 1964, Zottoli 1974, Cazaux 1982, Clavier 1984). The eggs of shallow water ampharetids sink, in some cases sticking 
to the bottom for a few days after fertilization, and emerging lecithotrophic larvae are demersal (Thorson 1946. Nyholm 1951, Clavier 1984). The relatively large eggs of A. galapagensis $(200 \mu \mathrm{m})$ probably produce non-feeding demersal larvae or develop directly into crawl-away juveniles. We have yet to find larvae or early stage juveniles of $A$. galapagensis; the earliest juvenile stages retrieved have 9 setigers (pers. obs.). We propose, therefore, that $A$. galapagensis undergoes lecithotrophic larval development near the bottom. The longest planktonic period recorded for ampharetid larvae is 3 to $5 \mathrm{~d}$ in Melinna cristata (Nyholm 1951). Metabolism may be reduced at the low ambient temperature around vents (ca $2^{\circ} \mathrm{C}$ ), making it impossible to confidently predict the length of larval life of vent polychaetes based on studies of shallow water species.

The maximum fecundity of Amphisamytha galapagensis, 12500 oocytes, is comparable to estimates for shallow water polychaetes that undergo non-feeding larval development (George 1964, Olive 1970, Fauchald 1983, Gremare \& Olive 1986), and the vent alvinellid polychaete Paralvinella palmiformis (McHugh 1989). If $A$. galapagensis does reproduce continuously, then each breeding event may involve just a portion of the eggs in the coelom. Nonetheless, fecundity in A. galapagensis is much higher than that of the only other ampharetid for which an estimate exists; Hypaniola kowalewskii, which is comparable in size and reproduces continuously, spawns 40 to 110 eggs at a time (Marinescu 1964) and undergoes direct development within the maternal tube.

The proposed life history features of Amphisamytha galapagensis are continuous reproduction, external fertilization and non-feeding, demersal larval development. A short larval life would ensure that a vent population is maintained. We find large numbers of small individuals $(<5 \mathrm{~mm})$ associated with adults, which indicates more than 1 recruitment event, and recruitment experiments at and near vents confirm local repopulation (Van Dover et al. 1988, Tunnicliffe 1990). Recruitment to new sites within a ridge requires a dispersal mechanism of larvae. The strong along-ridge component to the movements of deep water (Thomson et al. 1990, Cannon et al. 1991) around vents may be important in providing such a mechanism.

The proposed life history does not explain the unique distribution of Amphisamytha galapagensis. While it has been suggested that long planktonic development promotes wide dispersal (e.g. Mileikovsky 1971, Scheltema 1986), the observation is not universal and many other factors may influence distribution patterns (Johannesson 1988). Active dispersal of A. galapagensis between northern and equatorial Pacific vent fields would be compromised by a short larval life; further dispersal across the Pacific is even less probable.
However, there are numerous examples of marine species with short-lived or brooded larvae that have wide geographic ranges; some authors describe mechanisms of adult dispersal by rafting or wafting (e.g. Highsmith 1985, Ó Foighil 1989, Martel \& Chia 1991). If this highly adaptable species has located a dispersal agent in the deep sea, it is not yet known.

The ecology of Amphisamytha galapagensis may contribute to its ability to become widely established. In addition to having the widest distribution, it also has the widest ecological range presently documented among the common vent species. Vent animals may enter distant provinces frequently but be unable to locate an appropriate habitat. The key to the wide distribution of $A$. galapagensis may lie in its ability to adapt to whatever habitat is available in a new site. Indeed, long-lived larvae may not be an advantage to a hot-vent animal with a localized habitat. As Johannesson (1988) points out, the colonizing potential of short dispersers may be higher, as they can maintain a population once it becomes established.

Amphisamytha galapagensis is an exception to the high species endemism shown by vent communities of different provinces. A better understanding of its biology would contribute to interpretation of many aspects of vent biology, such as the roles of dispersal, habitat specialization, speciation and population structure in the development of vent communities. Studies on the systematics and population genetics of this species would make valuable contributions.

Acknowledgements. We thank NOAA Vents Program, Geological Survey of Canada and Department of Fisheries \& Oceans Canada for logistic support in collecting samples. Support by submersible crews of 'Alvin', 'Pisces IV' and 'Ropos' are gratefully acknowledged. Further contributions were made J. Delaney, University of Washington. Information on species counts was provided by $\mathrm{S}$. Mah, B. Milligan and T. Parker. D. Desbruyères kindly advised us on the identification of Atlantic and western Pacific specimens. The original manuscript was improved by the comments of 3 anonymous reviewers. This research was supported by the Natural Sciences and Engineering Research Council of Canada

\section{LITERATURE CITED}

Berg, C. J. Jr (1985). Reproductive strategies of mollusks from abyssal hydrothermal vent communities. In: Jones, M. L. (ed.) The hydrothermal vents of the eastern Pacific: an overview. Bull. biol. Soc. Wash. 6: 185-197

Berg, C. J., Van Dover, C. L. (1987). Benthopelagic macrozooplankton communities at and near deep-sea hydrothermal vents in the eastern Pacific Ocean and the Gulf of California. Deep Sea Res. 34A: 379-401

Campbell, A. C., Bowers, T. S., Measure, C. I., Falkner, K. K., Khadem, M., Edmond, J. M. (1988). A time series of vent fluid composition from $21^{\circ} \mathrm{N}$, East Pacific Rise $(1979,1981$, 1985) and the Guaymas Basin, Gulf of California (1982, 1985). J. geophys. Res. 93: 4537-4549 
Cannon, G. A., Pashinski, D. J., Lemon, M. R. (1991). Middepth flow near hydrothermal venting sites on the southern Juan de Fuca Ridge. J. geophys. Res. 96: 12815-12831

Cary, S. C., Felbeck, H., Holland, N. D. (1989). Observations on the reproductive biology of the hydrothermal vent tube worm Riftia pachyptila. Mar. Ecol. Prog. Ser. 52: 89-94

Cazaux, C. (1982). Développement larvaire de l'ampharetidae lagunaire Alkmaria romijni Horst 1919. Cah. Biol. mar. 23: 143-157

Chadwick, W. W., Embley, R. W., Fox, C. G. (1991). Evidence for volcanic eruption on the southern Juan de Fuca Ridge between 1981 and 1987. Nature 350:416-418

Clavier, J. (1984). Description du cycle biologique d'Ampharete acutifroms (Grube, 1860) (Annélide Polychète). C. r. hebd. Séanc. Acad. Sci., Paris (Sér. 3) 299: 59-62

Desbruyères, D., Gaill, F., Laubier, L., Fouquet, Y. (1985). Polychaetous annelids from hydrothermal vent ecosystems: an ecological overview. Bull. biol. Soc. Wash. 6: $103-116$

Desbruyères, D., Laubier, L. (1983). Primary consumers from hydrothermal vents animal communities. In: Rona, P. A., Bostrom, K., Laubier, L., Smith, K. L. Jr (eds.) Hydrothermal processes at seafloor spreading centers. Plenum Press, New York, p. 711-734

Eckelbarger, K. J. (1974). Population biology and larval development of the terebellid polychaete Nicolea zostericola. Mar. Biol. 27. 101-113

Eckelbarger, K. J., Grassle, J. P. (1987). Spermatogenesis, sperm storage and comparative sperm morphology in nine species of Capitella, Capitomastus and Capitellides (Polychaeta: Capitellidae). Mar. Biol 95: 415-429

Fauchald, K. (1983). Life diagram patterns in benthic polychaetes. Proc. biol. Soc. Wash. 96(1): 160-177

Galkin, S. V. (1992). Bottom fauna of the Manus Basin hydrothermal field. Oceanology 32: 1102-1110 (in Russlan)

Gardiner, S. L., Shrader, S. E., Jones, M. L. (1992). Preliminary observations on oogenesis in the tube worm Riftia pachyptila Jones (Vestimentifera). Am. Zool 32(5): 124A

George, J. D. (1964). The life history of the cirratulid worm, Cirriformia tentaculata and intertidal mudflat. J. mar. biol. Ass. U.K. 44: 47-65

Grassle, J. F. (1985). Hydrothermal vent animals: distribution and biology. Science 229: 713-717

Grassle, J. F., Brown-Leger, L. S., Morse-Porteous, L., Petrecca, R., Williams, I. (1985). Deep-sea fauna in the vicinity of hydrothermal vents. Bull. biol. Soc. Wash. 6: $443-452$

Gremare, A., Olive, P. J. W. (1986). A preliminary study of fecundity and reproductive effort in two polychaetous annelids with contrasting reproductive strategies. Int. J. Invert. Reprod. Dev. 9: 1-16

Guillou, M., Hily, C. (1983). Dynamics and biological cycle of a Melinna palmata (Ampharetidae) population during the recolonization of a dredged area in the vicinity of the harbour of Brest (France). Mar. Biol. 73: 43-50

Gustafson, R. G., Littlewood, D. T J., Lutz, R. A. (1991). Gastropod egg capsules and their contents from deep-sea hydrothermal vent environments. Biol. Bull. 180(1): 34-55

Hermans, C. O. (1979). Polychaete egg sizes, life histories and phylogeny. In: Stancyk, S. E. (ed.) Reproductive ecology of marine invertebrates. University of South Carolina Press, Columbia, p. 1-11

Hessler, R. R., Lonsdale, P. F. (1991). Biogeography of the Mariana Trough hydrothermal vents. Deep Sea Res. 38: 185-199

Highsmith, R. C. (1985). Floating and algal rafting as potential dispersal mechanisms in brooding invertebrates. Mar Ecol. Prog. Ser. 25: 169-179

Hutchings, P. A. (1973). Gametogenesis in a Northumberland population of the polychaete Melinna cristata. Mar. Biol. 18: $199-211$

Jamieson, B. G. M., Rouse, G.W (1989). The spermatozoa of the Polychaeta (Annelida): an ultrastructural review. Biol. Rev. 64: 93-157

Johannesson, K. (1988). The paradox of Rockall: why is a brooding gastropod (Littorina saxatulis) more widespread than one having a planktonic larval dispersal stage (L. littorea)? Mar. Biol. 99:507-513

Kennish, M. J., Lutz, R. A. (1992). The hydrothermal vent clam, Calytogena magnifica Boss and Tumer, 1980: a review of existing literature. Rev. aquat. Sci. 6(1): 29-66

Lalou, C., Labeyrie, L., Brichet, E., Perez-LeClaire, H. (1984) Les depôts hydrothermaux de la Dorsale Est-Pacifique: radiochronologie des sulfures et geochimie isotopique des depôts de silice. Bull. Soc. géol. Fr. 24: 9-14

Le Pennec, M., Hily, A., Lucas, A. (1984). Structures gonadiques particuliéres d'un mytilidae profond des sources hydrothermales du Pacifique oriental. C. r. hebd. Acad. Sci., Paris (Sér. 3) 299: 725-730

Lutz, R. A., Jablonski, D., Rhoads, D. C., Turner, R. D. (1980). Larval dispersal of a deep-sea hydrothermal vent bivalve from the Galapagos Rift. Mar. Biol. 57. 127-133

MacDonald, K. C., Becker, K., Speiss, F. N., Ballard, R. D. (1980). Hydrothermal heat flux of the 'black smoker' vents on the East Pacific Rise. Earth planet. Sci, Lett. 48: 1-7

Marinescu, V. P. (1964). La reproduction et la développement des polychètes reliques Ponto-Caspiens de Danube: Hypaniola kowalewskii (Grimm) et Manayunkia caspica A. Rev. roum. Biol. (Sér. Zool.) 9: 87-100

Martel, A, Chia, F.-S. (1991). Drifting and dispersal of small bivalves and gastropods with direct development. J. exp. mar. Biol. Ecol. 150: 131-147

McHugh, D. (1989). Population structure and reproductive biology of two sympatric hydrothermal vent polychaetes, Paralvinella pandorae and P. palmiformis. Mar. Biol. 103: 95-106

McHugh, D. (1993). A comparative study of reproduction and development in the polychaete family Terebellidae. Biol. Bull. 185: 153-167

Mileikovsky, S. A. (1971). Types of larval development in marine bottom invertebrates, their distribution and ecological significance: a re-evaluation. Mar. Biol 10: $193-213$

Milligan, B. N., Tunnicliffe, $V$ (in press). Vent and non-vent faunas of Cleft Segment, Juan de Fuca Ridge and their relations to lava age. J. geophys. Res

Nyholm, K.-G. (1951). Contributions to the life history of the ampharetid, Melinna cristata. Zool. Bidr. Upps. 29: 79-93

0 Foighil, D. (1989). Planktotrophic larval development is associated with a restricted geographic range in Lasaea, a genus of brooding, hermaphroditic bivalves. Mar. Biol. 103: $349-358$

Okuda, S. (1947). On an ampharetid worm, Schistocomus sovjeticus Annenkova, with some notes on its larval development. J. Fac. Sci. Hokkaido Imp. Univ. 9: 321-329

Olive, P. J. W. (1970). Reproduction of a Northumberland population of the polychaete Cirratulus cirratus. Mar. Biol. 5 $259-273$

Petrecca, R., Grassle, J. F. (1990). Notes on fauna from several deep-sea hydrothermal vent and cold seep soft-sediment communities. In: McMurray, G. R. (ed ) Gorda Ridge. Springer-Verlag, New York, p. 278-284

Rice, S. A. (1992). Spermatogenesis and spermiogenesis. In 
Harrison, F. W., Gardiner, S. L. (eds.) Microscopic anatomy of invertebrates, Vol. 7, Annelida. Wiley-Liss, New York, p. $129-152$

Rouse, G. W., Jamieson, B. G. M. (1987). An ultrastructural study of the spermatozoa of the polychaetes Eurythoe complanata (Amphinomidae), Clymenella sp. and Micromaldane $\mathrm{sp}$. (Maldanidae), with a definition of sperm types in relation to reproductive biology. $J$ submicrosc. Cytol. 19: 573-584

Sawada, N. (1984). Electron microscope studies of spermiogenesis in polychaetes. Fortschr. Zool. 29: 99-114

Scheltema, R. S. (1986). On dispersal and planktonic larvae of benthic invertebrates: an eclectic overview and summary of problems. Bull. mar. Sci. 39: 290-322

Segonzac, M. (1992). Les peuplements associés à l'hydrothermalisme océanique du Snake Pit (dorsale Médio-Atlantique; $23^{\circ} \mathrm{N}, 3480 \mathrm{~m}$ ) : composition et microdistribution de la mégafaune. C. r. hebd. Acad. Sci., Paris (Sér. 3), 314 : $593-600$

Stakes, D. S., Moore, W. S. (1989). Ages of hydrothermal vents on the Juan de Fuca Ridge. EOS Trans. Am. geophys. Un 70: 1164 (abstract)

Strathmann, R. R., Vedder, K. (1977). Size and organic content of eggs of echinoderms and other invertebrates as related to developmental strategies and egg eating. Mar. Biol. 39: 305-309

Thomson, R. E., Roth, S. E., Dymond, J. (1990). Near-inertial motions over a mid-ocean ridge: effects of topography and hydrothermal plumes. J. geophys. Res. 95: 7261-7278

Thorson, G. (1946). Reproduction and larval development of Danish marine bottom invertebrates, with special reference to the planktonic larvae in the sound (Oresund). Meddr Kommn. Danm. Fisk -og Havunders. 4 (1): 1-523

Thorson, G. (1950). Reproductive and larval ecology of marine bottom invertebrates. Biol. Rev. 25: 1-45

Tunnicliffe, V. (1988). Biogeography and evolution of hydrothermal-vent fauna in the eastern Pacific Ocean.

This article was submitted to the editor
Proc. R. Soc. London, Ser. B. 233: 347-366

Tunnicliffe, V. (1990). Observations on the effects of sampling on hydrothermal vent deposits and animals. J. geophys. Res. 95: 12961-12966

Tunnicliffe, V. (1991). The biology of hydrothermal vents: ecology and evolution. Oceanogr. mar. Biol. A. Rev. 29: $319-407$

Tunnicliffe, V., Desbruyères, D., Jollivet, D., Laubier, L. (1993). Systematic and ecological characteristics of Paralvinella sulfincola Desbruyeres \& Laubier, a new polychaete (family Alvinellidae) from northeast Pacific hydrothermal vents. Can. J. Zool. 7 1: 286-297

Turner, R. D., Lutz, R. A., Jablonski, D. (1985). Modes of molluscan larval development at deep-sea hydrothermal vents. Bull. biol. Soc. Wash. 6: 167-184

Van Dover, C. L. (1990). Biogeography of hydrothermal vent communities along seafloor spreading centers. Trends Ecol. Evol. 5: 242-246

Van Dover, C. L., Berg, C. J., Turner, R. D. (1988). Recruitment of marine invertebrates to hard substrates at deepsea hydrothermal vents on the East Pacific Rise and Galapagos spreading center. Deep Sea Res. 35A: $1833-1849$

Van Dover, C. L., Factor, J. R., Williams, A. B., Berg, C. J. (1985). Reproductive patterns of decapod crustaceans from hydothermal vents. Bull. biol. Soc. Wash 6: 223-227

Wesenberg-Lund, E. (1934). A viviparous brackish-water ampharetid, Alkmaria rominji Horst from Ringkjøbing Fjord. Vidensk. Meddr dansk. naturh. Foren. 98: 215-222

Zottoli, R. A. (1974), Reproduction and larval development of the ampharetid polychaete Amphicteis floridus. Trans. Am. microsc. Soc. 93(1): 78-89

Zottoli, R. A. (1983). Amphisamytha galapagensis, a new species of ampharetid polychaete from the vicinity of abyssal hydrothermal vents in the Galapagos Rift, and the role of this species in rift ecosystems. Proc. biol. Soc. Wash. 96: $379-391$

Manuscript first received: June 8, 1993

Revised version accepted: October 26, 1993 